\title{
Restoration of the biodiversity of technogenic landscapes of anthracite deposits in Siberia
}

\author{
Natalia Sokolova*, Sergey Solovyev, and Denis Sokolov \\ Institute of Soil Science and Agrochemistry SB RAS, Russia
}

\begin{abstract}
The features of self-restoring of plant communities in connection with the edaphic conditions of the dumps of anthracite deposits are revealed. It is shown that the development of tree communities is confined to areas with bumpy terrain, and grassy to horizontal areas.
\end{abstract}

\section{Introduction}

Open-pit coal mining is accompanied by the complete destruction of biocenoses and the soil cover of the mining areas. On the rocks left on the surface after development, through self-healing, the restoration of biocenoses occurs on the principle of primary catastrophic successions. The settlement of higher vegetation is accompanied by the formation of young soils that replace each other in the process of evolution and syngenetically to stages of succession of biocenoses [1-2]. Due to the fact that man-made landscapes are composed of a chaotic mixture of rocks, their surface is characterized by a high degree of spatial heterogeneity in the composition and density of substrates, as well as relief. This heterogeneity differentiates the edaphic conditions. As a result, within the same technogenic landscape, the restoration of biogeocenoses, and consequently of biological diversity, can occur in different directions and with different rates at different sites [3]. The purpose of this study is to identify the dependence of biodiversity indicators on the soilecological state of technogenic landscapes.

\section{Materials and methods}

\subsection{Objects of research}

The technogenic landscapes of the Nagorny dump of the Gorlovsky anthracite deposit, located in the Novosibirsk region, were selected as the objects of research. The study sites differ in age, surface topography, and the composition of the surface substrates. For the botanical description, 10 sites were selected, including planned and areas with bumpy terrain filled with dense rocks of different ages, as well as areas of loose rock filling.

* Corresponding author: nsokolova@issa-siberia.ru 


\subsection{Methods of research}

The soil-ecological state (SES) of the sites was estimated in points, which were calculated taking into account the content of organic carbon, the density of substrate, the content of physical clay and the capacity of cation exchange (CCE) of soils [4]. For this purpose, samples were taken of each type of young soils corresponding to a certain stage of the development of the biogeocenosis: initial, organo-accumulative and turf embryosems [5]. The parameters of soil properties were determined by the State Standart methods generally accepted in soil science [6]. Since the ratio of young soils varied for each site, the integral SES point was calculated as a weighted average (based on the point for each type of soil and the relative area of soil on the site).

The botanical description was carried out on the same sites with a size of $10 \times 10 \mathrm{~m}$ and was performed on standard forms for their systematization and standardization of the obtained data. To compare the floral lists of the studied sites, the Jaccard similarity coefficient was used [7-8].

\section{Results}

In the soil cover of technogenic landscapes of the Gorlovsky anthracite deposit, several types of young soils - embryosems, representing a consistent evolutionary series, are identified: initial embryosemes (identified in the areas of man-made eluvium filling flattenned (EIef) and unflattenned (EIeb)); organo-accumulative embryosemes (in the areas of man-made eluvium filling - on flattenned (EOAef) and unflattenned (EOAeb) and filling with loose rocks - clays (EOAc)) ; turf embryosemes (on flattenned areas of man-made eluvium (ETef) and loose rock - clay - (ETc) filling).

For each type of soil in technogenic landscapes, the points of the soil-ecological state are calculated. For this purpose, the coefficients of specificity are introduced in relation to the best soil in the adjacent natural areas - luvic protocalcic chernozems (Ch). The parameters of young soils - embryosems - were correlated with the parameters of zonal soil and the average coefficient of specificity was calculated (Table 1). The points of the soilecological state reflect the degree of compliance with the zonal soil in terms of the realization of their ecosystem functions by the soils.

Table 1. Calculation of the SES points of the main types of soils.

\begin{tabular}{|c|c|c|c|c|c|c|c|c|c|c|}
\hline $\begin{array}{l}\text { Soil } \\
\text { type }\end{array}$ & $\begin{array}{c}\text { Corg, } \\
\%\end{array}$ & $\mathrm{Cs}_{\mathbf{C}}$ & $\begin{array}{c}\text { PC, } \\
\%\end{array}$ & $\mathrm{Cs}_{\mathrm{PC}}$ & $\begin{array}{c}\text { Density, } \\
\mathrm{g}^{\prime} / \mathrm{cm}^{3}\end{array}$ & $\mathbf{C s}_{\mathbf{D}}$ & $\begin{array}{c}\text { CCE, } \\
\text { mg- } \\
\text { equiv/ } \\
100 \mathrm{~g}\end{array}$ & $\begin{array}{c}\text { Cs } \\
\text { CCE }\end{array}$ & $\mathrm{Cs}_{\mathrm{av}}$ & $\begin{array}{l}\text { SES, } \\
\text { point }\end{array}$ \\
\hline EIef & 2.9 & 0.84 & 1.8 & 0.04 & 2.2 & 0.50 & 5.0 & 0.12 & 0.38 & 37.5 \\
\hline EOAef & 2.4 & 0.69 & 7.5 & 0.18 & 1.7 & 0.65 & 14.0 & 0.33 & 0.46 & 46.3 \\
\hline ETef & 4.6 & 0.62 & 9.5 & 0.23 & 1.5 & 0.73 & 25.0 & 0.60 & 0.54 & 54.2 \\
\hline EIeb & 2.9 & 0.86 & 1.8 & 0.04 & 1.7 & 0.64 & 8.0 & 0.19 & 0.43 & 43.3 \\
\hline EOAeb & 5.1 & 1.49 & 6.4 & 0.15 & 1.6 & 0.69 & 11.0 & 0.26 & 0.65 & 64.9 \\
\hline ETc & 0.7 & 0.20 & 59.6 & 1.42 & 1.5 & 0.73 & 37.0 & 0.88 & 0.81 & 80.6 \\
\hline EOAc & 0.3 & 0.10 & 61.0 & 1.45 & 1.3 & 0.85 & 36.0 & 0.85 & 0.81 & 81.3 \\
\hline $\mathrm{Ch}$ & 3.4 & 1.00 & 42.0 & 1.00 & 1.1 & 1.00 & 45.0 & 1.00 & 1.00 & 100.0 \\
\hline
\end{tabular}

Notes. Cs - coefficient of specificity; Corg - the content of organic carbon; PC - the content of physical clay; $\mathrm{CCE}$ - the capacity of cation exchange; $\mathrm{Cs}_{\mathrm{av}}$ - average coefficient of specificity; $\mathrm{SES}$ the soil-ecological state . 
Botanical descriptions were carried out on 10 key sites, 8 of which were filled with dense rocks ( 4 with flattened and 4 with bumpy terrain, aged from 10 to 30 years), 1 with dense rocks with an admixture of clays and 1 with loose rocks - clays.

Table 2. Description of the key sites studied

\begin{tabular}{|c|c|c|c|c|c|c|c|c|c|}
\hline \multirow{2}{*}{$\begin{array}{c}\text { Site } \\
\text { numbe } \\
\mathbf{r}\end{array}$} & \multirow[b]{2}{*}{$\begin{array}{l}\text { Age, } \\
\text { years }\end{array}$} & \multirow[b]{2}{*}{ Type of phytocenosis } & \multicolumn{3}{|c|}{ Number of species } & \multirow[b]{2}{*}{$\begin{array}{l}\text { Pc,* } \\
\%\end{array}$} & \multicolumn{2}{|c|}{ Relation } & \multirow[b]{2}{*}{$\begin{array}{c}\text { SES } \\
\text { points }\end{array}$} \\
\hline & & & Woody & $\begin{array}{c}\text { Herba- } \\
\text { ceous }\end{array}$ & Total & & $\begin{array}{l}\text { soil } \\
\text { types }\end{array}$ & $\mathrm{S}_{0} / \mathrm{S}_{\mathrm{s}} * *$ & \\
\hline 1 & $20-25$ & Birch forest & 1 & 8 & 9 & 80 & $1.0 \mathrm{EOA}$ & 1.03 & 46.3 \\
\hline 2 & $>25$ & Mixed forest & 3 & 10 & 15 & 90 & $\begin{array}{c}0.2 \mathrm{EI} / \\
0.8 \mathrm{EOA} \\
\end{array}$ & 1.26 & 60.5 \\
\hline 3 & $>25$ & $\begin{array}{l}\text { Mixed grass meadow } \\
\text { with reforestation }\end{array}$ & 4 & 18 & 22 & 70 & $\begin{array}{c}0.2 \mathrm{EI} / \\
0.7 \mathrm{EOA} / \\
0.1 \mathrm{ET}\end{array}$ & 1.00 & 45.6 \\
\hline 4 & $10-15$ & Ruderal groupings & 0 & 7 & 7 & 10 & $1.0 \mathrm{ET}$ & 1.00 & 37.5 \\
\hline 5 & $15-20$ & Mixed forest & 3 & 16 & 21 & 90 & $\begin{array}{c}0.1 \mathrm{EI} / \\
0.9 \mathrm{EOA}\end{array}$ & 1.17 & 63.8 \\
\hline 6 & $20-25$ & Mixed forest & 2 & 6 & 9 & 90 & \begin{tabular}{|c|}
$0.2 \mathrm{EI} /$ \\
$0.8 \mathrm{EOA}$ \\
\end{tabular} & 1.10 & 60.5 \\
\hline 7 & $15-20$ & $\begin{array}{l}\text { Mixed-grass-legume- } \\
\text { cereal meadow }\end{array}$ & 1 & 19 & 21 & 95 & $\begin{array}{c}0.3 \mathrm{EOA} / \\
0.7 \mathrm{ET}\end{array}$ & 1.11 & 80.6 \\
\hline 8 & $20-25$ & $\begin{array}{l}\text { Mixed-grass-cereal } \\
\text { meadow }\end{array}$ & 2 & 18 & 20 & 90 & $\begin{array}{c}0.4 \mathrm{EOA} / \\
0.6 \mathrm{ET}\end{array}$ & 1.00 & 51.4 \\
\hline 9 & $15-20$ & Mixed-grass meadow & 2 & 15 & 17 & 75 & \begin{tabular}{|c|}
$0.5 \mathrm{EI} /$ \\
$0.5 \mathrm{EOA}$ \\
\end{tabular} & 1.00 & 41.9 \\
\hline 10 & $10-15$ & Ruderal groupings & 0 & 6 & 6 & 5 & $1.0 \mathrm{EI}$ & 1.20 & 43.3 \\
\hline
\end{tabular}

Notes. ${ }^{*} \mathrm{Pc}$ - projective cover; ${ }^{* *}$ relation of squares of: $\mathrm{S}_{0}-$ base (horizontal surface), $\mathrm{S}_{\mathrm{s}}-$ site surface.

For each key site, points of the soil-ecological state are calculated based on the ratio of the soil types on them (Table 2). In addition, the correlation coefficients of SES points with the total number of species, the number of woody and herbaceous species, as well as with the projective cover are calculated (Table 3 ).

Table 3. Correlations of botanical parameters with the SES of the study sites

\begin{tabular}{|c|c|c|c|c|}
\hline Parameters & $\begin{array}{c}\text { Total number of } \\
\text { species }\end{array}$ & Woody & Herbaceous & $\begin{array}{c}\text { Projective } \\
\text { cover }\end{array}$ \\
\hline $\begin{array}{c}\text { Correlation } \\
\text { coefficients }\end{array}$ & 0.47 & 0.21 & 0.39 & 0.66 \\
\hline
\end{tabular}

\section{Discussion}

The calculation of the similarity coefficients of the Jaccard for the species composition of vegetation showed (Fig. 1) that the most closely related group of sites covered with forest vegetation (mixed forests) and the adjacent site, which is at the stage of overgrowth with ruderal vegetation; common to this cluster is the bumpy terrain. It provides the differentiation of moisture on the surface of the plots, which in turn contributes to the formation of woody vegetation. However, there is a separate cluster consisting of two sections: a birch forest and a mixed-grass-legume-cereal meadow. Despite the fact that the birch forest was formed on a site with a flattened terrain and on a substrate with an 
increased density (up to 2.0), the implementation of the flushing water regime is carried out due to the overall slope of the site $\left(\mathrm{S}_{0} / \mathrm{Sp}=1.03\right)$.. At the same time, the increased content of physical clay in the soil (59.6\%), apparently, hinders the development of woody vegetation in the area where the mixed grass-legume-cereal meadow is located.

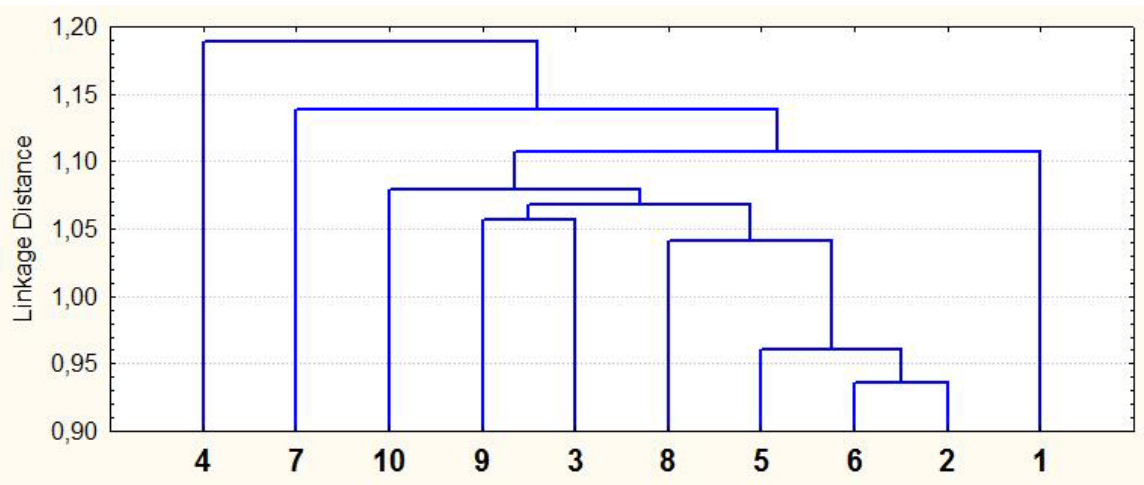

Fig.1. The similarity of the studied sites in the species composition of vegetation (according to the calculated values of the Jaccard coefficient)

Thus, the woody vegetation and its characteristic plant species composition, which is formed in the process of overgrowth of the transport dump of the Gorlovsky anthracite deposit, are confined to soils with a bumpy terrain. Among other things, an important role is played by the age of the filling area, as well as the properties of the substrate and the method of surface formation. It should be noted that in forest communities, over time, the total number of species first increases and then decreases, which is associated with the elimination of ruderal pioneer species from the phytocenosis. Herbaceous species tend to flattened sites and develop especially abundantly on loose substrates.

\section{References}

1. V.M. Kurachev, E.R. Kandrashin, F.K. Ragim-Zade, Siberian Journal of Ecology 1,7 (1994)

2. Y.A. Manakov, T.O. Strelnikova, A.N. Kupriyanov, Formation of vegetable cover in man-general landscapes of Kuzbass (EDP SB RAS, Novosibirsk, 2011)

3. D.A. Sokolov, Diversification of soil formation on dumps of coal deposits in Siberia (ISSA SB RAS, Novosibirsk, 2019)

4. V.A. Androkhanov, V.M. Kurachev, Contemporary problems of ecology 2,6 (2009)

5. D.A. Sokolov, S.P. Kulizhskiy Tomsk State University. Journal of Biology 27,3 (2014)

6. M.Pansu, J. Gautheyrou. Handbook of Soil Analysis. Mineralogical, Organic and Inorganic Methods (Springer-Verlag Berlin Heidelberg, 2006)

7. P. Jaccard Bull. Soc. Vaudoise Sci. Natur. 37 (1901)

8. V.M. Schmidt, Mathematical Methods in Botany (Leningrad Publishing House University, Leningrad, 1984) 